\title{
Litter traits and palatability to detritivores: a case study across bio-geographical boundaries
}

\author{
Aline Ferreira Quadros*, Martin Zimmer, Paula Beatriz Araujo and Jair Gilberto Kray
}

(AFQ) (PBA) Programa de Pós-Graduação em Biologia Animal, Departamento de Zoologia, Universidade Federal do Rio Grande do Sul, Av. Bento Gonçalves, 9500, 91501-970, Porto Alegre, RS, Brazil. E-mail: (AFQ) quadros.af@gmail.com, ${ }^{*}$ Corresponding author

(MZ) Zoologisches Institut, Christian-Albrechts-Universität zu Kiel, Kiel, Germany; Present address: Leibniz-Center for Marine Tropical Ecology (ZMT) GmbH, Bremen, Germany;

(JGK) Programa de Pós-Graduação em Botânica, Departamento de Botânica, Universidade Federal do Rio Grande do Sul, Porto Alegre, Brazil;

\begin{abstract}
The activity of the litter-feeding macrofauna affects litter decomposition rates at the local scale, and their preference for particular litter types is mediated by litter traits. Environmental changes such as invasion by exotic plants may change the characteristics of the litter at a local scale, with consequences to ecosystem processes. Here we evaluated the feeding preferences of four detritivores (terrestrial isopods) from two biogeographic regions (neotropical and palearctic), offering them native or non-native litter in cafeteria experiments. Our results show that isopods from different geographical regions exhibit essentially the same food preference, irrespective of whether or not they previously had encountered the litter tested. Combining the isopods' preference ranks with the principal component analysis of nine litter traits, we show that preference increases with increasing nitrogen and calcium contents and decreases with increasing toughness, $\mathrm{C}: \mathrm{N}$ ratio and thickness, irrespective of the geographical origin of both litter and detritivores. We conclude that the palatability of a non-native litter to the native detritivore community can be predicted from their respective litter traits and thus, native detritivores will feed on a particular non-native litter type as likely as do detritivores in the native range of the plant. As the combination of traits that indicates palatability to the isopods also indicates litter decomposability, it could be possible to predict ecosystem responses in terms of litter decomposition rates upon changes in litter composition.
\end{abstract}

Key Words: Detritivory, feeding preferences, litter traits, terrestrial isopods

\section{INTRODUCTION}

Decomposition of plant litter is shaped by environmental factors, among which climatic conditions, soil properties, litter characteristics and microbial and faunal activity have been considered pivotal (Swift et al., 1979; Wall et al., 2008). Among different biomes, climate is the main factor controlling decomposition rates (Meentemeyer, 1978; Aerts, 1997; Gholz et al., 2000; Liski et al., 2003). However, under the same climatic conditions and even within a particular ecosystem, decomposition rates of different litter types are known to differ widely (Kakazou et al., 2009; Makkonen et al., 2012). These differences in litter decomposability have been mainly attributed to the initial litter characteristics (litter traits), especially nitrogen, cellulose and lignins (Meentemeyer, 1978; Melillo et al., 1982; Pérez-Harguindeguy et al., 2000; Kurokawa et al., 2010). The activity of the litter-feeding macrofauna can accelerate decomposition, as has been 
shown by observing mass loss in exclosure experiments in the field (Meyer, 2008; Smith et al., 2009; Rouifed et al., 2010) and in the laboratory (Tian et al., 1992; Vos et al., 2011; Treplin and Zimmer, 2012). Among the many possible ways by which the macrofauna could influence decomposition rates, one is through selective feeding on particular litter types (Hättenschwiller and Bretscher, 2001). Selective feeding by detritivores has been reported often and, alike decomposability, it is considered to be mediated by litter traits that indicate its nutrient and/or lignocellulose content (Dudgeon et al., 1990; Hendriksen, 1990; Ashwini and Sridhar, 2005; Catalán et al., 2008) and also by colonization by microorganisms (Ihnen and Zimmer, 1998). Understanding which particular litter traits govern both palatability to detritivores and decomposability can improve our ability to predict how decomposition processes will be affected upon changes in litter traits, be it through climate change (Cotrufo et al., 1998; Hättenschwiler et al., 1999; Kasurinen et al., 2007) or through changes in the species composition of the vegetation (Mack and D'Antonio, 2003; Ashton et al., 2005). One situation of particular interest is the change in decomposition rates after invasion by exotic plant species (Vitousek, 1990; Ehrenfeld, 2003), where either increased or decreased mass loss rates have been documented (Ehrenfeld, 2003; Ashton et al., 2005; Bastow et al., 2008). If both palatability and decomposability were mediated by similar traits, it would be possible to predict whether a positive or negative feedback will take place upon invasion by comparing the native versus the exotic litter traits. However, while there is a substantial amount of research using litter traits to explain decomposability (Tian et al., 1992; Cornelissen et al., 1999; PérezHarguindeguy et al., 2000; Cornwell et al., 2008), which litter traits determine litter palatability to detritivores and its generality is less understood. Here we investigate this relationship, and we hypothesize that (1) feeding preferences of different detritivores species are governed by the same suite of traits and (2) the litter traits that govern food preferences of detritivores are independent of whether detritivores had previously contact with a particular litter type to acclimate with or adapt to. To test this hypothesis, we offered neotropical or palearctic litter to either neotropical or palearctic terrestrial isopods in common cafeteria experiments. With this set-up we expected to simulate the introduction of non-native plant species to a native community of detritivores.

\section{Material And Methods Isopod species}

For this study we chose two terrestrial isopods that are common to temperate deciduous forests of Europe (Palearctic) and two species common to the Atlantic forest of Brazil (Neotropical). The palearctic species pair was Porcellio scaber Latreille, 1804 (Porcellionidae) and Philoscia muscorum (Scopoli, 1763) (Philosciidae). The neotropical species pair was Atlantoscia floridana (van Name, 1940) (Philosciidae) and Balloniscus glaber Araujo \& Zardo, 1995 (Balloniscidae), which are common and abundant isopods in southern Brazil (Quadros and Araujo, 2007; 2008). P. scaber and $P$. muscorum were sampled in the vicinity of Kiel, northern Germany, and $B$. glaber and A. floridana were sampled in Porto Alegre, southern Brazil.

\section{Collection of leaf litter}

The palearctic plant species chosen for the study were common deciduous trees of temperate forests inhabited by $P$. scaber and $P$. muscorum (Zimmer, 2002a): Acer pseudoplatanus L. (Sapindaceae), Alnus glutinosa L. (Betulaceae), Betula pendula Roth (Betulaceae), Quercus robur L. (Fagaceae) and Fagus sylvatica L. (Fagaceae). Leaf litter from these trees were collected in the vicinity of Kiel immediately upon fall, from single-species stands of at least ten trees each, air-dried and stored at $10^{\circ} \mathrm{C}$. To determine the most common litter types available in the area where the neotropical isopods were sampled, we took 40 litter samples within an 1 ha area using a $30 \mathrm{~cm}$ 
diameter corer for further processing in the laboratory. We used an exsiccate collection to determine the identity of the leaves in each corer sample and found four species to be very common in the area: Myrsine umbellata Mart. (Primulaceae) occurred in $87 \%$ of the samples, Lithraea brasiliensis Marchand (Anacardiaceae) in $80 \%$, Machaerium stipitatum (DC.) Vogel (Fabaceae) in 67\% and Roupala brasiliensis Klotzsch (Proteaceae) in 45\%. These four species were then selected for the feeding trials. To exchange the litter between countries, batches of $\sim 100 \mathrm{~g}$ of each litter type were airdried during one week, packed and sealed in plastic containers.

For clarity sake, henceforth plants and isopods will be referred to by their genus.

\section{Plant leaf traits}

We thoroughly browsed the literature for litter traits available for the above mentioned plants species. We used nine traits commonly considered to govern leaf litter decomposition and consumer preferences (Hendriksen, 1990; Zimmer, 2002b; Cornelissen et al., 2004; Kurokawa et al., 2010): toughness, thickness, lignins and cellulose (indicators of litter structural resistance), N, P, Ca and C:N ratio (indicators of litter nutrient content) and total phenolics (indicator of secondary compounds). When more than one value was found for the same litter type, an average was calculated. When authors provided a range of values, the maximum and minimum were included and used to calculate the mean value. In the case of selected neotropical litter, however, there was no such data available in the literature and thus the traits were obtained in the laboratory using standard techniques. Leaf thickness was obtained using a digital caliper. Leaf toughness was obtained with a penetrometer following the method of Graça and Zimmer (2005). Total phenolics were determined as described in Bärlocher and Graça (2005), using commercially available tannic acid as standard. For these two assays we used 10 leaves of each species. Lignins and cellulose were measured following Van Soest et al. (1991). Total nitrogen and carbon were measured in a $\mathrm{C} / \mathrm{N}$ Analyzer. Total $\mathrm{Ca}$ and $\mathrm{P}$ were obtained using the atomic absorption assay. These last assays were performed on a bulk of leaves (approx. $500 \mathrm{~g}$ of each species). Even though data gathered from the literature presents variation due to differences in litter age, methods and place of collection, some general patterns could be distinguished.

\section{Feeding assays}

We conducted multi-choice feeding experiments with both neotropical and palearctic isopods, either offering a choice among the four neotropical litter types or among the five palearctic litter types. To homogenize the initial conditions of the litter, only intact leaves with similar brown coloration were used. This sorting was done manually for all litter types. Adult isopods at an intermoult stage were captured on the same day the assays started. Air temperature was maintened constant at $20^{\circ} \mathrm{C}$ during all experiments.

The experiments with palearctic woodlice, Porcellio and Philoscia, were conducted in Kiel, Germany. The feeding arenas consisted of plastic boxes (6 $\mathrm{cm}$ diameter), lined with plaster, and a small brick piece was added to provide moisture and shelter, respectively. In these assays, consumption was accessed as the amount of food eaten (in $\mathrm{mg}$ ). For that purpose, leaves were cut into pieces and dried at $45^{\circ} \mathrm{C}$ for $48 \mathrm{~h}$. About $5 \mathrm{mg}$ of each food type was offered to the isopods. At the end of the choice test, the remaining food was dried again $\left(45^{\circ} \mathrm{C}, 48 \mathrm{~h}\right)$ and weighed. The experiments with neotropical isopods, Balloniscus and Atlantoscia, were conducted in Brazil. Feeding arenas were made of Petri dishes of $15 \mathrm{~cm}$ diameter, lined with plaster to provide moisture and a plastic shelter. Each arena contained three leaf discs $(6 \mathrm{~mm}$ diameter) of each plant species and one isopod. Using a stereomicroscope and milimetric paper, the area $\left(\mathrm{mm}^{2}\right)$ of each food type eaten was measured. Further, area eaten was multiplied by leaf thickness (obtained with a digital caliper) to yield the amount consumed 
as leaf volume $\left(\mathrm{mm}^{3}\right)$. Fifteen replicates per treatment were set initially, but final numbers ranged from 12 to 15 , due to mortality. The trials were stopped when approximately half of the most consumed food was eaten.

At the end of the feeding trials we calculated the amount eaten from each litter type as well as the total amount of food eaten, either as $\mathrm{mg}$ (for paleartic isopods) or $\mathrm{mm}^{3}$ (for neotropical isopods), for each replicate. Then we expressed the consumption as a percentage of the total amount eaten. This procedure allowed for comparison of the results even though the methods used to estimate consumption differed between neotropical and palearctic isopods.

\section{Data analysis}

The litter traits of neotropical and palearctic species were ordinated with a principal component analysis (PCA) of our dataset (11 traits $\mathrm{x} 9$ plant species) using PAST (Hammer et al., 2001). For each combination of isopod species and litter origin we compared the relative consumption of the litter type by multiple pairwise comparisons with resampling. This procedure was done using the resampling functions provided in PopTools

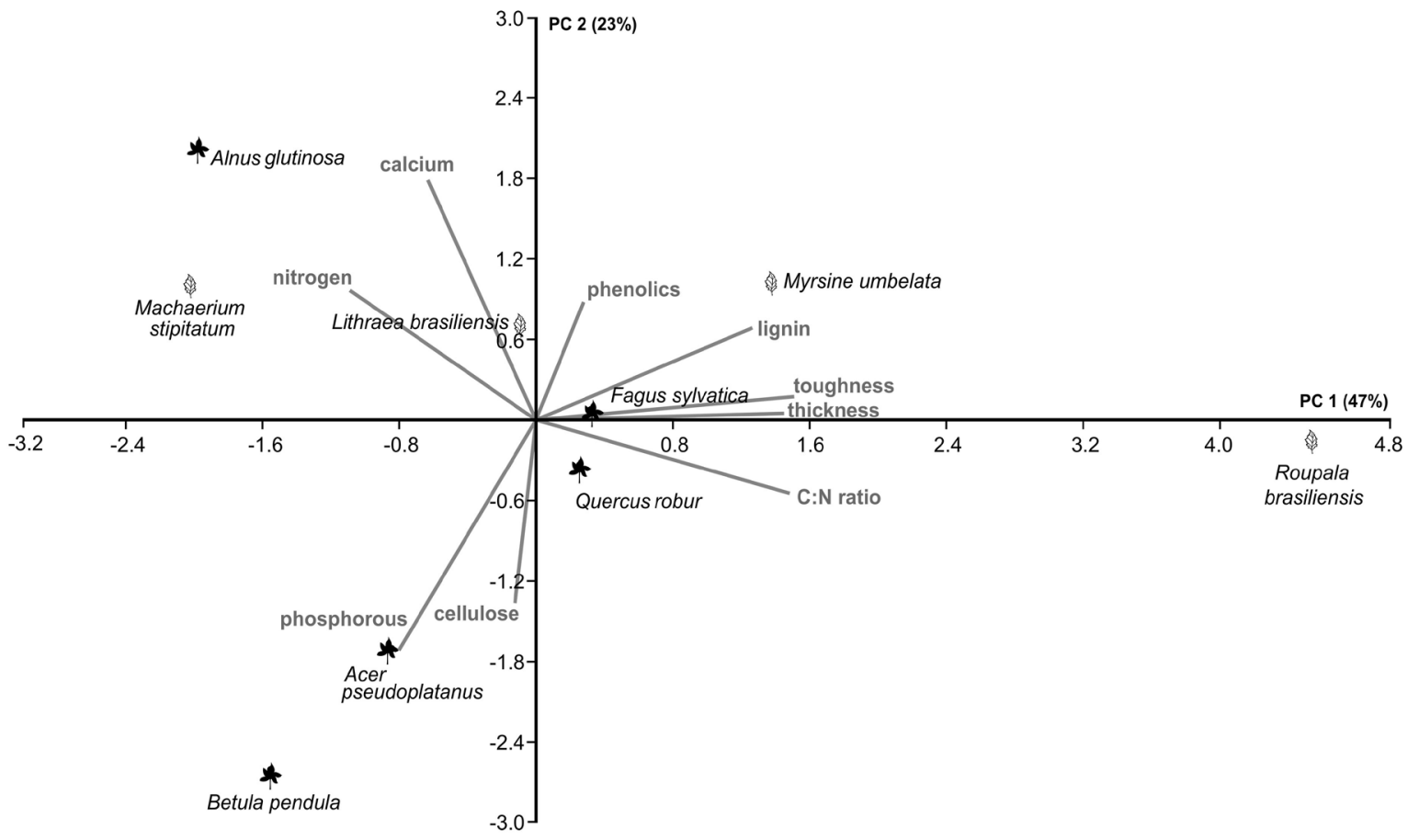

(Hood, 2010). To access the relationship between the observed food preference and the litter traits, the amount consumed of each plant by each isopod species (in relation to the total consumed) was correlated to the litter position along the principal components (given by the PCA scores), as in Díaz et al. (2004). For this analysis we used a bootstrapped Pearson correlation, and we included the first two PCA axes, as they explained the largest part of the variance.

\section{RESULTS}

The litter types markedly differed from each other with respect to those traits commonly considered relevant (PCA: Fig. 1). The first PCA axis shows a clear distinction between tough and nutrient-poor litter (Roupala) and the softer and nutrient-rich (nitrogen, calcium) litter types (Machaerium and Alnus), with all other litters intermediate to these two extremes (Fig. 1). Along the second PCA axis, Alnus is also separated from the other litters due to its higher calcium content (Fig. 1). We also noted little differentiation between the neotropical litter types along axis 2 (Fig. 1).

Figure 1. Principal component analysis of nine litter traits of four neotropical (white symbols) and five palearctic (black symbols) deciduous tree species (only axes 1 and 2 are shown, which explained $70 \%$ of total variance). 

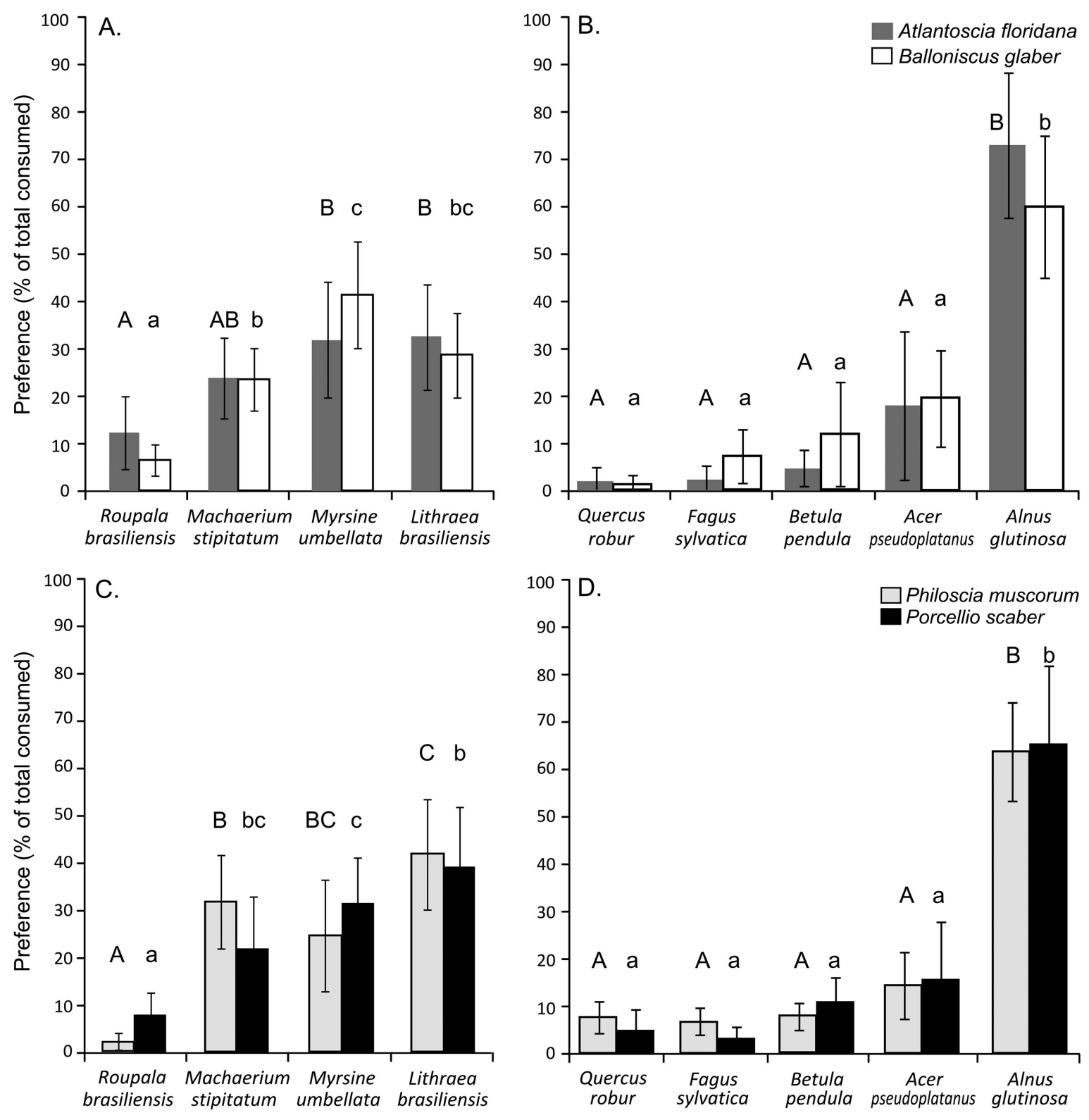

neotropical litter

palearctic litter

Figure 2. Feeding preferences of terrestrial isopods. A. Neotropical isopods x neotropical plants. B. Neotropical isopods x palearctic plants. C. Palearctic isopods x neotropical plants. D. Palearctic isopods x palearctic plants. Values indicate the relative consumption of each plant from the total amount consumed in multiple-choice feeding trials (mean $\pm 95 \%$ c.i. in \%). Different letters indicate significant differences between plant species (t-test with bootstrapping). Capital letters refer to $A$. floridana (on A and $\mathrm{B}$ ) and $P$. muscorum (on C and D) and small letters refer to B. glaber (on A and B) and P. scaber (on C and D).

According to our hypotheses, food preferences by different isopods were very similar when neotropical litter was offered (Fig. $2 \mathrm{~A}, 2 \mathrm{C}$ ) and exactly the same when palearctic litter was offered (Fig. 2B, 2D). Amongst the neotropical litter types, Roupala was always the least consumed, while Myrcine, Lithrea and Machaerium were consumed in similar proportions (Fig. 2A, 2C). When palearctic litter was offered, isopod preference was very evident towards Alnus litter. Alnus constituted more than $60 \%$ of the total amount consumed, while the other four species represented from $5 \%$ to $20 \%$ of the total amount eaten (Fig. 2B, D).

By crossing the preference ranks obtained in the multi-choice experiments with the ordination of plant traits, we show that the feeding preferences of both palearctic and neotropical isopods were negatively correlated 
to the position of plants along PCA axis 1 (Pearson $r=-0.43, P=0.0037$ ) (Fig. 3A) and positively correlated with axis 2 (Pearson $\mathrm{r}=$ $0.57, \mathrm{P}=0.0001$ ) (Fig. 3B). This correlation indicates that food preferences increase with decreasing toughness, $\mathrm{C}: \mathrm{N}$ ratio, thickness and lignins, while it increases as calcium and nitrogen content increases (Fig. 3).

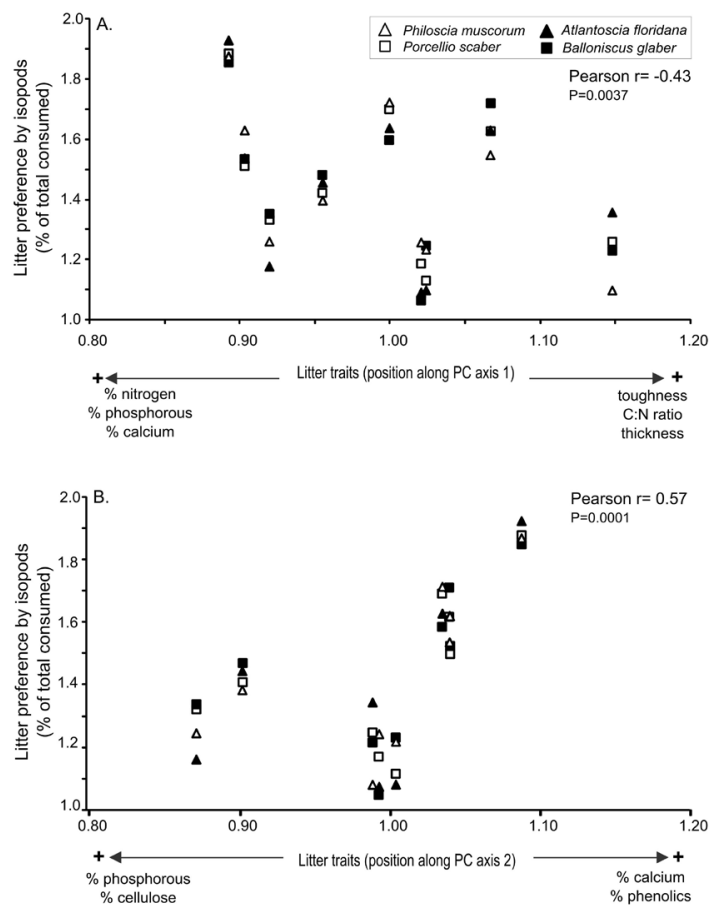

Figure 3. Correlation (bootstrapped Pearson's correlation) between litter preference by neotropical and palearctic isopods and the respective litter traits (summarized by the position of each litter type along the two principal component axes; see Fig. 1). A. Correlation of isopods preference and the litter position along principal component 1 (PC 1). B. Correlation of isopods preference and the litter position along principal component 2 (PC 2). Both axes are shown log-transformed.

\section{Discussion}

Our present findings clearly indicate that terrestrial isopods of distant families and distant bio-geographical locations show common food preferences. They also suggest that detritivores, irrespective of potential acclimation with, or adaptation to, locally prevailing litter types, choose their preferred food sources upon a limited number of litter traits. This finding has implications for our prognostication on how the litter of non-native plant species will be decomposed through the action of native detritivore communities, since feeding preferences for non-native can be predicted from (a) feeding preferences in their native ranges and (b) relatively few litter traits.

Our results demonstrate that terrestrial isopods are able to distinguish between litter types and that litter palatability is determined by a combination of important nutrients, here nitrogen and calcium, and the mechanical resistance of the leaves, expressed by their thickness, toughness and its correlates (lignins, $\mathrm{C}: \mathrm{N}$ ratio). The multivariate analysis of the selected litter traits clearly separates Roupala from the other neotropical litter and Alnus from the other palearctic litter. Accordingly, in the preference rank of the four isopod species tested, these two litter types stand out as the least and most preferred, respectively, as compared with the other litter offered simultaneously.

When given a choice among litter types that differed largely with respect to thickness and toughness, as was the case for the neotropical litter, isopods clearly avoided excessively tough litter (here: Roupala). These results are in accordance with previous findings that, if given a chance, isopods will prefer the litter with lower amounts of lignins (Soma and Saitô, 1983; Catalán et al., 2008). Thick, tough and lignin-rich litter such as Roupala is most probably avoided because it makes the chewing of the plant material by the mouthparts difficult or even unviable, if the litter is tougher than the mouthparts (Sanson, 2006). When a litter with high contents of nutrients and low toughness, lignins and $\mathrm{C}: \mathrm{N}$ ratio was available, as was the case for Alnus compared to the other litter of palearctic origin, it was readily and intensely consumed while the others were left aside. This combination of high nutrient content with low thickness/ toughness and its correlates is commonly associated with high decomposability, as it is indeed the case for Alnus (Wedderburn and Carter, 1999; Pérez-Corona et al., 2006). Amongst the neotropical litter, however, Machaerium litter was also nitrogen-rich and presented very low thickness/toughness, but it was not consumed in a greater proportion than the other two, Myrcine and Lithraea. This might indicate the presence of a feeding 
deterrent that was not addressed in the present study, such as terpenes and alkaloids that could be offsetting its beneficial traits.

Although calcium is not a nutrient commonly included as descriptor of litter quality, our results (and also Dugdeon et al., 1990) point to its importance as indicator of palatability to detritivores. Calcifying soil invertebrates depend on calcium and it is known that low $\mathrm{pH}$ that interferes with calcium availability restricts isopod distribution (Zimmer et al., 2000) and population growth (Zimmer and Topp, 1997). Considering litter, the main food source to macrodetritivores, it is likely that food preference would have implications for fitness. Indeed, isopods ( $P$. scaber) have higher growth rates when feeding on Alnus litter and lower growth efficiency when feeding on tougher litter (Souza et al., 1998). Thus, it seems that the more palatable a litter is to detritivores, the higher fitness benefits it will provide (Rushton and Hassall, 1983; Zimmer and Topp, 2000) and there is likely a positive feedback of litter traits on decomposition rates by maintaining and/or increasing detritivore populations.

As the present results demonstrate, the litter traits most commonly associated with low decomposability - high thickness, toughness, lignins and $\mathrm{C}: \mathrm{N}$ ratios and low nutrient content (Taylor et al., 1989; Cornelissen et al., 1999) - also indicate low palatability to important macrodetritivores such as terrestrial isopods. Having this correlation in mind, we can expect that changes in litter quality induced by environmental changes will affect food selection and overall litter consumption by the macrofauna, with consequences for decomposition and nutrient mineralization (Hättenschwiler and Bretscher, 2001). It could be possible to predict the direction of the effect that changing litter traits will have on decomposition rates, based on the differences between the native and exotic litter. For instance, Cameron and Spencer (1989) reported an increase in decomposition and nutrient cycling following invasion by a plant that produced faster decomposable litter (low lignin: $N$ ratio) than the natives, and the exotic litter was consumed by the isopod Armaddillidium vulgare, an important detritivore in the area. On another situation, the litter produced by an invasive grass had a high C: $\mathrm{N}$ ratio and, as expected, was rejected by $P$. scaber (Bastow et al., 2008). In this case, the litter accumulated in invaded areas and decomposition rates decreased (Bastow et al., 2008). By observing that isopods from different geographical regions exhibit essentially the same food preference, we conclude that it is not the status of being non-native that determines palatability of a particular litter type but its traits. Thus, native isopods (and maybe macrodetritivores in general, see Dunger, 1958) will feed on a particular non-native litter type as likely as do isopods in the native range of the plant. Hence, the palatability of a non-native litter to the native detritivore community could be predicted from the respective litter traits.

ACKNOWLEDGEMENTS - The authors wish to express their gratitude to the Deutscher Akademischer Austauschdienst - DAAD (Rio de Janeiro's office) for a grant given to A.F. Quadros. We would like to thank Malte Mews, Kristina Brandstädter, Nicole Stange, Hanno Baehrs and Sabine Geisler for their kindness and assistance during the experiments. Finally, we thank CAPES and CNPq for the grants given to AFQ and PBA, respectively.

\section{REFERENCES}

Aerts, R. 1997. Climate, leaf litter chemistry and leaf litter decomposition in terrestrial ecosystems: a triangular relationship. Oikos, 79: 439-449.

Ashton, I.W.; Hyatt, L.A.; Howe, K.M.; Gurevitch, J. and Lerdau, M.T. 2005. Invasive species accelerate decomposition and litter nitrogen loss in a mixed deciduous forest. Ecological Applications, 15: 12631272.

Ashwini, K.M. and Sridhar, K.R. 2005. Leaf litter preference and conversion by a saprophagous tropical pill millipede, Arthrosphaera magna Attems. Pedobiologia, 49: 307-316.

Bärlocher, F. and Graça, M.A.S. 2005. Total phenolics. p. 97-100. In: M.A.S Graça, F. Bärlocher and M.O. Gessner (eds.), Methods to Study Litter Decomposition: A Practical Guide. Berlin, Springer.

Bastow, J.L.; Preisser, E.L. and Strong, D.R. 2008. Holcus lanatus invasion slows decomposition through its interaction with a macroinvertebrate detritivore, Porcellio scaber. Biological Invasions, 10: 191-199.

Cameron, G.N. and Spencer, S.R. 1989. Rapid leaf decay and nutrient release in a chinese tallow forest. Oecologia, 80: 222-228. 
Catalán, T.P.; Lardies, M.A. and Bozinovic, F. 2008. Food selection and nutritional ecology of woodlice in Central Chile. Physiological Entomology, 33: 8994.

Cornelissen, J.H.C.; Pérez-Harguindeguy, N.; Díaz, S.; Grime, J.P.; Marzano, B. and Cabido, M. 1999. Leaf structure and defense control litter decomposition rate across species and life forms in regional floras on two continents. New Phytologist, 143: 191-200.

Cornelissen, J.H.C.; Quested, H.M.; Gwynn-Jones, D.; Van Logtestijn, R.S.P.; De Beus, M.A.H.; Kondratchuk, A.; Callaghan, T.V. and Aerts, R. 2004. Leaf digestibility and litter decomposability are related in a wide range of subarctic plant species and types. Functional Ecology, 18: 779-786.

Cornwell, W.K.; Cornelissen, J.H.C.; Amatangelo, K.; Dorrepaal, E.; Eviner, V.T.; Godoy, O.; Hobbie, S.E.; Hoorens, B.; Kurokawa, H.; Perez-Hardeguindeguy, N.; Quested, H.M.; Santiago, L.S.; Wardle, D.A.; Wright, I.J.; Aerts, R.; Allison, S.D.; van Bodegom, P.; Brovkin, V.; Chatain, A.; Callaghan, T.V.; Díaz, S.; Garnier, E.; Gurvich, D.E.; Kazakou, E.; Klein, J.A.; Read, J.; Reich, P.B.; Soudzilovskaia, N.A.; Vaieretti, M.V. and Westoby, M. 2008. Plant species traits are the predominant control on litter decomposition rates within biomes worldwide. Ecology Letters, 11: 1065-1071.

Cotrufo, M.F.; Briones, M.J.I. and Ineson, P. 1998. Elevated $\mathrm{CO}$ affects field decomposition rate and palatability of tree leaf litter: importance of changes in substrate quality. Soil Biology and Biochemistry, 30: $1565-1571$.

Díaz, S.; Hodgson, J.G.; Thompson, K.; Cabido, M.; Cornelissen, J.H.C.; Jalili, A.; MontserratMartí, G.; Grime, J.P.; Zarrinkamar, F.; Asri, Y.; Band, S.R.; Basconcelo, S.; Castro-Díez, P.; Funes, G.; Hamzehee, B.; Khoshnevi, M.; PérezHarguindeguy, N.; Pérez-Rontomé, M.C.; Shirvany, F.A.; Vendramini, F.; Yazdani, S.; Abbas-Azimi, R.; Bogaard, A.; Boustani, S.; Charles, M.; Dehghan M.; de Torres-Espuny, L.; Falczuk, V.; Guerrero-Campo, J.; Hynd, A.; Jones, G.; Kowsary, E.; Kazemi-Saeed, F.; Maestro-Martínez, M.; Romo-Díez, A.; Shaw, S.; Siavash, B.; Villar-Salvador, P. and Zak, M.R. 2004. The plant traits that drive ecosystems: Evidence from three continents. Journal of Vegetation Science, 15: 295-304.

Dudgeon, D.; Ma, H.H.T. and Lam, P.K.S. 1990. Differential palatability of leaf litter to four sympatric isopods in a Hong Kong forest. Oecologia, 84: 398-403.

Dunger, W. 1958. Uber die Zersetzung der Laubstreu durch die Boden-Makrofauna im Auenwald. ZoologischeJahrbücher. Abteilung für Systematik, Ökologie und Geographie der Tiere, 86: 139-180.

Ehrenfeld, J.G. 2003. Effects of exotic plant invasions on soil nutrient cycling processes. Ecosystems, 6: 503523.

Gholz, H.L.; Wedin, D.A.; Smitherman, S.M.; Harmon, M.E. and Parton, W.J. 2000. Longterm dynamics of pine and hardwood litter in contrasting environments: toward a global model of decomposition. Global Change Biology, 6: 751-765.

Graça, M.A.S. and Zimmer, M. 2005. Leaf toughness. p. 121-126. In: M.A.S Graça, F. Bärlocher and M.O. Gessner (eds.), Methods to Study Litter Decomposition: A Practical Guide. Berlin, Springer
Hammer, Ø.; Harper, D.A.T. and Ryan, P.D. 2001. PAST: Paleontological Statistics software for education and data analysis. Paleontologia Electronica, 4:1-9.

Hättenschwiler, S. and Bretscher, D., 2001. Isopod effects on decomposition of litter produced under elevated $\mathrm{CO}_{2}, \mathrm{~N}$ deposition and different soil types. Global Change Biology, 7: 565-579.

Hättenschwiler, S.; Bühler, S. and Körner, C. 1999. Quality, decomposition and isopod consumption of tree litter produced under elevated $\mathrm{CO}_{2}$. Oikos, 85, 271-281.

Hendriksen, N.B. 1990. Leaf litter selection by detritivore and geophagous earthworms. Biology and Fertility of Soils, 10: 17-21.

Hood, G.M. 2010. PopTools version 3.2.5. Available at http://www.poptools.org.Accessed on 20 October 2014.

Ihnen, K. and Zimmer, M. 2008. Selective consumption and digestion of litter microbes by Porcellio scaber (Isopoda: Oniscidea). Pedobiologia, 51: 335-342.

Kasurinen, A.; Peltonen, P.A.; Julkunen-Tiitto, R.; Vapaavuori, E.; Nuutinen, V.; Holopainen, T. and Holopainen, J.K. 2007. Effects of elevated $\mathrm{CO}_{2}$ and $\mathrm{O}^{3}$ on leaf litter phenolics and subsequent performance of litter-feeding soil macrofauna. Plant and Soil, 292: 25-43.

Kazakou, E.; Violle, C.; Roumet, C.; Pintor, C.; Gimenez, O. and Garnier, E. 2009. Litter quality and decomposability of species from a Mediterranean succession depend on leaf traits but not on nitrogen supply. Annats of Botany, 104: 1151-1161.

Kurokawa, H.; Peltzer, D.A. and Wardle, DA. 2010. Plant traits, leaf palatability and litter decomposability for co-occurring woody species differing in invasion status and nitrogen fixation ability. Functional Ecology, 24: 513-523.

Liski, J.; Nissinen, A.; Erhard, M. and Taskinen, O. 2003. Climatic effects on litter decomposition from arctic tundra to tropical rainforest. Global Change Biology, 9: 575-584.

Mack, M.C. and D'Antonio, C.M. 2003. The effects of exotic grasses on litter decomposition in a hawaiian woodland: the importance of indirect effects. Ecosystems, 6: 723-738.

Makkonen, M.; Berg, M.P.; Handa, I.T.; Hättenschwiler, S.; van Ruijven, J.; van Bodegom, P.M. and Aerts, R. 2012. Highly consistent effects of plant litter identity and functional traits on decomposition across a latitudinal gradient. Ecology Letters, 15: 1033-1041.

Mayer, P.M. 2008. Ecosystem and decomposer effects on litter dynamics along an old field to old-growth forest successional gradient. Acta Oecologica, 33: 222-230.

Meentemeyer, V. 1978. Macroclimate and lignin control of litter decomposition rates. Ecology, 59: 465-472.

Melillo, J.M.; Aber, J.D. and Muratore. J.F. 1982. Nitrogen and lignin control of hardwood leaf litter decomposition dynamics. Ecology, 63: 621-626.

Pérez-Corona, M.E.; Pérez Hernández, M.C. and Castro, F.B. 2006. Decomposition of Alder, Ash, and Poplar litter in a Mediterranean Riverine area. Communications in Soil Science and Plant Analysis, 37: 1111-1125.

Pérez-Harguindeguy, N.; Díaz, S.; Cornelissen, J.H.C.; Vendramini, F.; Cabido, M. and Castellanos, A. 2000. Chemistry and toughness predict leaf litter decomposition rates over a wide spectrum of functional types and taxa in central Argentina. Plant and Soil, 218: 21-30. 
Quadros, A.F. and Araujo, P.B. 2008. An assemblage of terrestrial isopods (Crustacea) in southern Brazil and its contribution to leaf litter processing. Revista Brasileira de Zoologia, 25: 58-66.

Quadros, A.F. and Araujo, P.B. 2007. Ecological traits of two neotropical oniscideans (Crustacea: Isopoda). Acta Zoologica Sinica, 53: 241-249.

Rouifed, S.; Handa, I.T.; David, J.F. and Hättenschwiler, S. 2010. The importance of biotic factors in predicting global change effects on decomposition of temperate forest leaf litter. Oecologia, 163: 247256.

Rushton, S.P. and Hassall, M. 1983. The effects of food quality on the life history parameters of the terrestrial isopod (Armadillidium vulgare (Latreille)). Oecologia 57: 257-261.

Sanson, G. 2006. The biomechanics of browsing and grazing. American Journal of Botany, 93: 1531-1545.

Smith, J.; Potts, S.G.; Woodcock, B.A. and Eggleton, P. 2009. The impact of two arable field margin management schemes on litter decomposition. Applied Soil Ecology, 41: 90-97.

Soma, K. and Saitô, T. 1983. Ecological studies of soil organisms with references to the decomposition of pine needles II. Litter feeding and breakdown by the woodlouse, Porcellio scaber. Plant and Soil, 75: 139151.

Sousa, J.P.; Vingada, J.V.; Loureiro, S.; da Gama, M.M. and Soares, A.M.V.M. 1998. Effects of introduced exotic tree species on growth, consumption and assimilation rates of the soil detritivore Porcellio dilatatus (Crustacea: Isopoda). Applied Soil Ecology, 9: 399-403.

Swift, M.J.; Heal, O.W. and Anderson, J.M. 1979. Decomposition in terrestrial ecosystems. Oxford, Blackwell, 372p.

Taylor, B.R.; Parkinson, D. and Parsons, W.F.J. 1989. Nitrogen and lignin content as predictors of litter decay rates: a microcosm test. Ecology, 70: 97-104.

Tian, G.; Kang, B.T. and Brussaard, L. 1992. Biological effects of plant residues with contrasting chemical compositions under humid tropical conditions Decomposition and nutrient release. Soil Biology \& Biochemistry, 24: 1051-1060.

Treplin, M. and Zimmer, M. 2012. Drowned or dry: a cross-habitat comparison of detrital breakdown processes. Ecosystems, 15: 477-491.

Van Soest, P.J.; Robertson, J.B. and Lewis, B.A. 1991. Methods for dietary fiber, neutral detergent fiber, and nonstarch polysaccharides in relation to animal nutrition. Journal of Dairy Science, 74: 3583-3597.

Vitousek, P.M. 1990. Biological invasions and ecosystem processes: towards an integration of population biology and ecosystem studies. Oikos, 57: 7-13.

Vos, V.C.A.; van Ruijven, J.; Berg, M.P.; Peeters, E.T.H.M. and Berendse, F. 2011. Macro-detritivore identity drives leaf litter diversity effects. Oikos, 120: 1092-1098.

Wall, D.H.; Bradford, M.A.; St. John, M.G.; Trofymow, J.A.; Behan-Pelletier, V.; Bignell, D.E.; Dangerfield, M.; Parton, W.J.; Rusek, J.; Voigt, W.; Wolters, V.; Gardel, H.Z.; Ayuke, F.O.; Bashford, R.; Beljakova, O.I.; Bohlen, P.J.; Brauman, A.; Flemming, S.; Henschel, J.R.; Johnson, D.L.; Jones, T.H.; Kovarova, M.; Kranabetter, J.M.; Kutny, L.; KuoChuan, L.; Maryati, M.; Masse D.; Pokarzhevskii, A.; Rahman, H.; Sabara, M.G,; Salamon, J-A.; Swift, M.J.; Varela, A.; Vasconcelos, H.L.; White, D. and
Zou, X. 2008. Global decomposition experiment shows soil animal impacts on decomposition are climate dependent. Global Change Biology, 14: 1-17.

Wedderburn, M.E. and Carter, J. 1999. Litter decomposition by four functional tree types for use in silvopastoral systems. Soil Biology \& Biochemistry, 31: 455-461.

Zimmer, M. 2002a. Is decomposition of woodland leaf litter influenced by its species richness? Soil Biology \& Biochemistry, 34: 277-284.

Zimmer, M. 2002b. Nutrition in terrestrial isopods (Isopoda: Oniscidea): an evolutionary-ecological approach. Biological Review, 77: 455-493.

Zimmer, M.; Brauckmann, H-J.; Broll, G. and Topp, W. 2000. Correspondence analytical evaluation of factors that influence soil macro-arthropod distribution in abandoned grassland. Pedobiologia, 44: 695-704.

Zimmer, M. and Topp, W. 1997. Does leaf litter quality influence population parameters of the common woodlouse, Porcellio scaber (Crustacea:Isopoda)? Biology and Fertility of Soils, 24: 435-441.

Zimmer, M. and Topp, W. 2000. Species-specific utilization of food sources by sympatric woodlice (Isopoda: Oniscidea). Journal of Animal Ecology, 69: 1071-1082. 